\title{
Cytopathology of Saliva in COVID-19 Patients: Preliminary Study on Five Patients of COVID-19
}

Mohammad Zulkarnain ${ }^{1 \dagger}$, Rostika Flora ${ }^{2 \dagger *}$, Nyiayu Fauziah ${ }^{3}$, Citra Dewi ${ }^{3}$, Eny Rahmawati ${ }^{4}$, Yusri Yusri ${ }^{5}$, Lisa Dewi ${ }^{6}$,

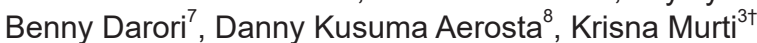

${ }^{1}$ Department of Public Health Sciences, Faculty of Medicine, Sriwijaya University, Palembang, Indonesia; ${ }^{2}$ Postgraduate Program for Public Health Sciences, Faculty of Public Health, Sriwijaya University, Palembang, Indonesia; ${ }^{3}$ Department of Anatomic Pathology, Faculty of Medicine, Sriwijaya University, Mohammad Hoesin Hospital, Palembang, Indonesia; ${ }^{4}$ Department of Clinical Pathology and Laboratory Medicine, Faculty of Medicine, Sriwijaya University, Mohammad Hoesin Hospital, Palembang, Indonesia; ${ }^{5}$ Regional Health Office for South Sumatra Province, South Sumatra, Indonesia; ${ }^{6}$ Health Laboratory Center, Palembang, South Sumatra, Indonesia; ${ }^{7}$ Mohammad Hoesin Hospital, Palembang, South Sumatra, Indonesia; ${ }^{8}$ Postgraduate Student of Public Health Sciences, Faculty of Public Health, Sriwijaya University, Palembang, Indonesia

Abstract

Edited by: Branislav Filipović Citation: Zulkarnain M, Murti K, Flora R, Rahmawati Yusri M, Dewi L, Darori B, Aerosta DK, Fauziah N. Cytopathology of Saliva in COVID-19 Patients: Preliminary Study on Five Patients of COVID-19. Open Access Mace J Med Sci. 2021 Jan 23; 9(A):68-72. https://doi.org/10.3889/oamjms.2021.5572 Keywords: SARS-CoV-2; Saliva; Epithelial cells; Cell membrane Correspondence: Rostika Flora, Postgraduate Program Sriwija Univerity Palombang, Indonesia. E-mail: rostikaflora@gmail.com Revise: 26-Dec-2020 These authors contributed equally to this work. TThese authors contributed equally to this work.
. Rostika Flora, Eny Rahmawati, Muhammad Yusri, Liza Dewi, Benny Darori, Danny Kusuma Aerosta, Nyiayu Fauziah Funding: This research was supported by a research Sriwijaya University. Competing Interests: The authors have declared that no competing interests exist

Open Access: This is an open-access article distributed under the terms of the Creative Commons AttributionNonCommercial 4.0 International License (CC BY-NC 4.0)
BACKGROUND: Coronavirus disease (COVID-19) is caused by a SARS-CoV-2 virus. The virus is currently known to possess single-stranded and positive-sense RNA genomes. The replication of this virus does not occur in the nucleus but in the cytoplasm of the host cell. This rapid replication can lead to impairment of host cell. Without cytoplasm, the host cell will lose its shape and may be damaged.

AIM: This study aims to find out the histopathology of exfoliated epithelial cells in saliva of COVID-19 patients.

METHODS: This was an observational study with a laboratory-based cross-sectional design. The specimens of saliva were collected from five positive people of COVID-19 and four people as negative controls of COVID-19. The determination of positive and negative infections of COVID-19 was based on the results of the real-time reverse transcription-polymerase chain reaction on nasopharyngeal swabs, oropharyngeal swabs, and sputum. The cytopathology of saliva was examined by Smear test and it was then stained by Papanicolaou method. The morphology of exfoliative epithelial cells in saliva was observed using a light microscope with magnification of $\times 10$ and $\times 40$. The damage of epithelial cells was observed from the integrity of the epithelial cell membrane and the shape of the damaged epithelial cells. In addition to morphologic findings, the number of cells with no nucleus was also calculated.

RESULTS: From five samples of saliva from patients of positive COVID-19, microscopically the membrane of epithelial cells was intact and the contents of the cells were scattered about. The damaged epithelial cells with nucle were in place, which were also found, but the morphology was not normal. More cells without nuclei were frequently observed in the saliva of COVID-19 patients.

CONCLUSION: The damage to membrane and organelles of epithelial cells was found in the saliva of COVID-19 patients.

\section{Introduction}

COVID-19 is a disease caused by the virus SARS-CoV-2. The disease was previously referred as a 2019 novel coronavirus (2019nCoV), but in February, the WHO announced a new official name that is the coronavirus disease (COVID-19) [1]. COVID-19 has spread and involved more than 198 countries in the world. As of May 26, 2020, the World Health Organization reported 5,404,512 confirmed cases and 343,514 deaths [2].

SARS-CoV-2 belongs to the broad family of viruses known as coronaviruses. The enveloped viruses possess extraordinarily large single-stranded RNA genomes with a three-dimensional structure in the receptor-binding domain (RBD) of the spike protein of SARS-CoV-2. The virus is able to invade the cell using angiotensin-converting enzyme 2 (ACE2) receptors [3]. Based on virus classification, viruses with single-stranded and positive-sense RNA genomes do not require a functional nucleus for replication, but they do so within the cytoplasm of the host cell [4]. Furthermore, SARS-CoV-2 duplicates its genetic material and synthesizes different required proteins, then buds out new virions [3], [4], [5]. A rapid replication and large number of replicon may lead to the damage to host cells. Without cytoplasm, the host cell will lose its shape and be impaired.

At present, the gold standard for diagnostic tests for SARS-CoV-2 is the real-time reverse transcription-polymerase chain reaction ( $\mathrm{rRT}-\mathrm{PCR}$ ) test. The specimens, as recommended by the $\mathrm{WHO}$, can be collected from the upper (nasopharyngeal 
or oropharyngeal swabs) or lower respiratory tract (sputum, bronchoalveolar lavage [BAL], or endotracheal aspirate) [6]. However, the collection of these specimen types may cause patients' discomfort. Besides, the sampling procedures may also expose the health workers because the sampling technique can cause the patients to sneeze or cough and cough out virus particles. Studies conducted in Hong Kong reported that SARS-CoV-2 can be detected in the self-collected saliva of $91.7 \%$ of COVID-19-positive patients [7]. Therefore, the use of saliva sample can be considered as an alternative non-invasive method of detection of SARS-CoV-2. This study was conducted to assess the cytopathology of exfoliative epithelial cells in saliva of patients with COVID-19 as an alternative option to detect the presence of the SARS-CoV-2 virus.

\section{Methods}

This research was a laboratory-based observational study with a cross-sectional design. The study was conducted in May 2020, at the Balai Besar Laboratorium Kesehatan Palembang (Palembang Health Laboratory Center). Saliva specimens were collected from five COVID-19 patients, and four negative COVID-19 people as controls. Regardless of disease duration, all saliva were collected at the same time to avoid multiple contact and risk of infecting of our staffs from COVID-19.

The determination of positive and negative for COVID-19 infections was based on the results of rRT-PCR test on swabs of nasopharyngeal, oropharyngeal, and sputum. The saliva specimen was mixed thoroughly by stirring, smeared evenly on a glass slide, and fixed with $96 \%$ alcohol for $30 \mathrm{~min}$. The smears were then stained with Papanicolaou method. The cytology of exfoliative epithelial cells in saliva was observed using a light microscope of Olympus CX33 with magnification of $10 x$ and $40 x$. The photographs of the cells were taken with an Indomicro HDMI camera mounted on the microscope. The damaged epithelial cells can be seen from the integrity of the membrane and organelles in the cytoplasm of the cells and the shape of damaged epithelial cells. In addition, the counting of epithelial cells without nuclei was also applied.

\section{Ethical approval}

This study has received an ethical approval from the Health Research Ethics Commission, Faculty of Public Health No. 183/UN9.1.10/KKE/2020.

\section{Results}

\section{patients \\ Cytopathic effects on saliva of COVID-19}

In COVID-19 patients, based on microscopic cytomorphology, the damage due to cytopathic effects was seen in the superficial and intermediate cells (Figure 1a-d) which were not found in the saliva of control group (Figure 1e and f) of uninfected people. These cytopathic effects were found in cells, in which the shape has already changed different compared with rounded or oval healthy cells. The cell membrane appeared to be damaged and no longer intact, and the contents of the cytoplasm were spattering out. In some abnormal cells, the damaged membrane was not obvious (Figure 1a). On the other hand, the nuclei of damaged cells still can be seen but not intact if compared with the one of other normal epithelial cells (Figure 1a-d). The origin of damaged cells was not clear whether they were from superficial or intermediate cells since the morphology of the nuclei was not also clearly observed after they broke apart. The cytoplasmic content of cells other than the nuclei or organelles can no longer be recognized morphologically. They looked like small pieces of various sizes scattered about the area that is thought to be remnants of cytoplasmic cells (Figure 2). Four out of the five patients were in the state of asymptomatic condition because they were volunteered being checked by health authority after having close contact with infected person before, and one was with mild fever. The onsets of the disease were varying from 4 to 14 days.

\section{Comparison of cells without nucleus between COVID-19 patients and control ones}

Based on the quantification of epithelial cells without nucleus, it was found that the number of cells loosing nuclei were higher than that in COVID-19 patients compared to control ones (Graph 1).

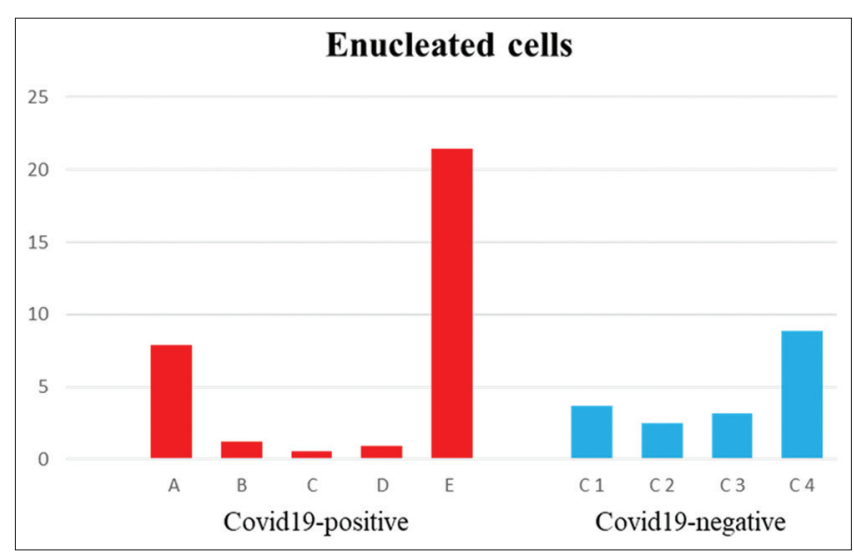

Graph 1: Comparison of cells without nuclei in COVID-19 patients in comparison to those of control. There is a tendency for cells without nuclei to be more common in the saliva of COVID-19 patients compared to saliva of control patients 


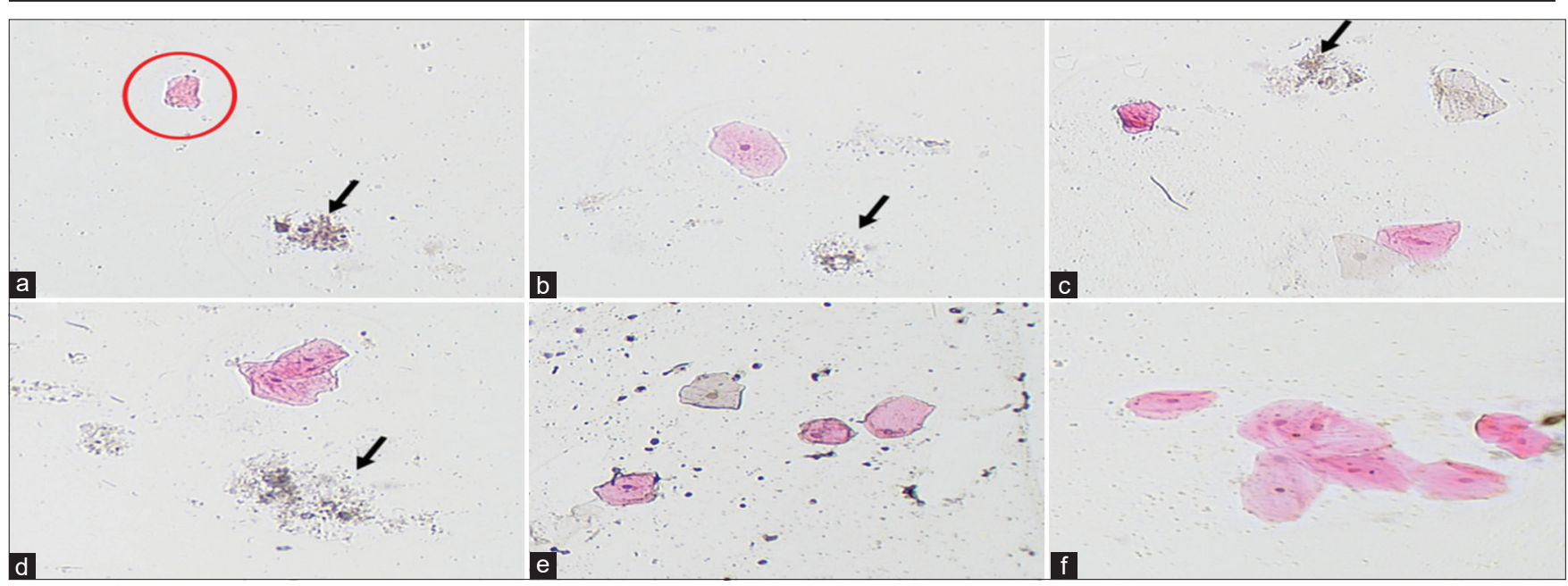

Figure 1: Cytopathic effect on salivary exfoliative cells (a-d). The cells with cytopathic effect (black arrows) and the superficial cells around still look like healthy cells microscopically. The origin of cells with cytopathic effect cannot be assessed since the nuclei have been ruptured. In a, a cell without nucleus (red circle). In e and $f$, the superficial and intermediate cells in the saliva of control group. Papanicolaou staining, $\times 10$ magnification

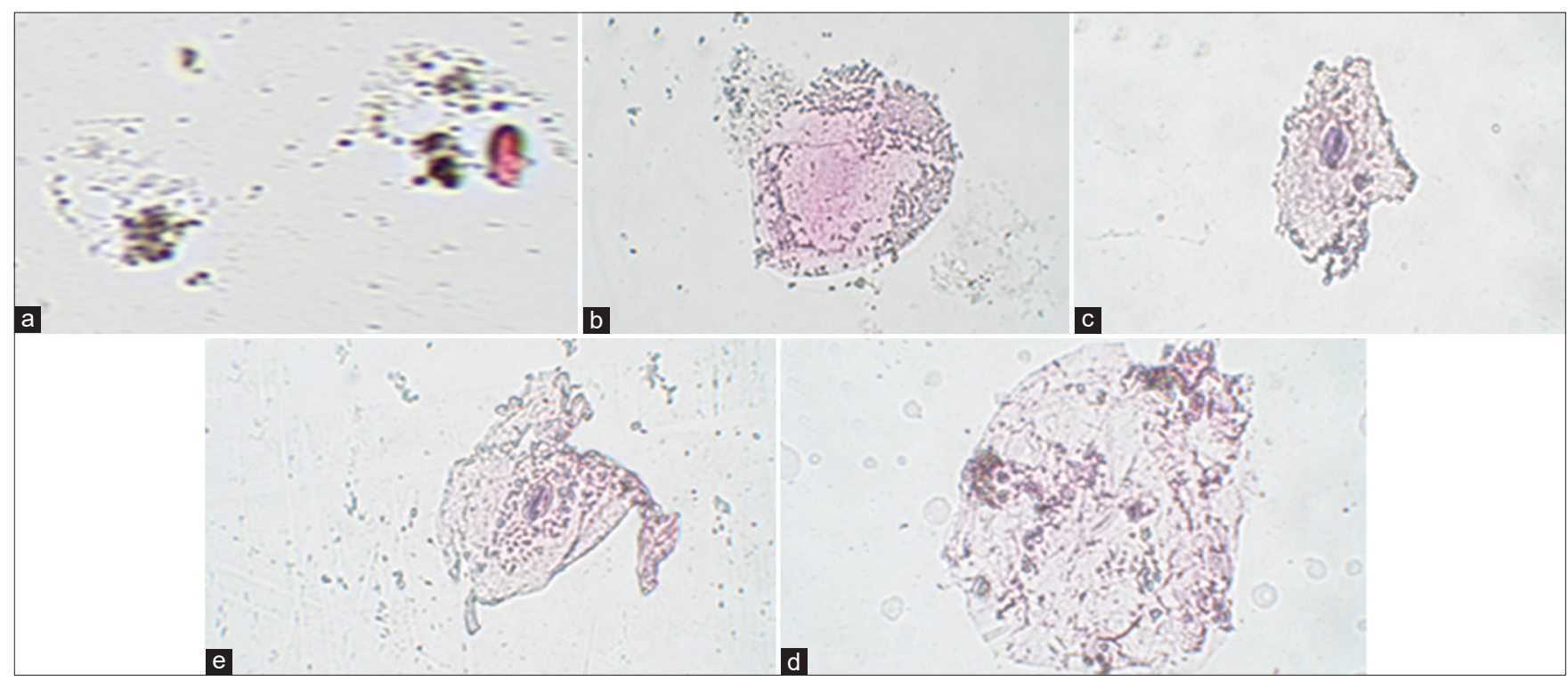

Figure 2: Cytopathic effect in salivary exfoliative cells of COVID 19 patients. The cell damage is extensive and very obvious. The cell membrane was not visible, and the nucleus is not present (a); the half of cell membrane was still present and some of the cell contents were scattered out, and the nucleus of the cell cannot be seen clearly (b); The cell membrane was still visible, and the cell contents have been seen scattered out. The nuclei were still visible but the cytoplasm has totally changed from its normal morphology (c and d); the cell membrane was partly damaged and the cell contents were scattered out. The cell nucleus was not visible and the cytoplasm has changed far from its normal morphology (e). Papanicolaou staining, $\times 40$ magnification

\section{Discussion}

This study examined exfoliative epithelial cells consisting of non-keratinized superficial and intermediate cells from squamous epithelium complex lining the oral mucosa. The non-keratinized superficial cells were round or oval, which have larger size with pyknotic nuclei, and ratio nuclear-cytoplasm is low. While the intermediate cells exhibited smaller size than the superficial cells but the nuclei were larger; hence, the ratio of nuclear-cytoplasm is bigger and the chromatin was brighter. In addition, another type of cells that were identified within the saliva was cells without nuclei (enucleated cells). These cells are the outer layer of squamous epithelial cells which loses their nuclei and easily exfoliate [8], [9], [10], [11]. This cytopathic effect is a viral property seen as a result of harmful mechanism of virus to the infected cells [12], [13].

Saliva with a variety of contents has been recently used as a parameter to detect the health status [14], [15]. It cannot be denied that the cytopathic effect on exfoliative cells in saliva is not only caused by SARS-CoV-2 infection. However, several other viruses found in saliva such as herpes simplex virus 1 (HSV-1) and human immunodeficiency virus (HIV) that can cause upper respiratory tract infections, mumps virus, and human papillomavirus (HPV) [16]. Although there 
are differences in the mechanism of cytopathic effects in all these viral infections; however, microscopic morphological studies on the cytopathic effect of saliva in particularly or on cytopathology in general have not been conducted so far.

The cytopathic effect was detected in the saliva of COVID-19 patients, while it was not detected in the group of people who were not infected in this study, it has not been known whether the effects were due to SARS-CoV-2 infection or due to infection of other microorganisms in the oral cavity. Therefore, for further research, the clinical data must be supplemented with those on the condition of the oral cavity followed by other examinations to ascertain this possibility and if necessary a molecular examination must be carried out on the same saliva to confirm the presence of the SARS-CoV-2 virus itself or other microorganisms.

Based on the morphology of damaged cells, patient A had more cells with severe damage. This is probably due to differences in the duration of COVID-19 infection. Saliva of patient A was collected on the 4th day of infection, while the samples of other patients were taken and examined on the 10th-14th day of infection. The saliva was taken in the same day for all patients because the collection permission was very strict at that time. For the next phase, it is important to matched the patients in terms of their time of infection. Presumably, in the early days of infection, there was high viral activity and a high viral load, affecting the number and severity of epithelial cell damage, because at this stage, patient antibodies have not been formed. Meanwhile, after the 7th day of infection, antibodies have been formed and of course will also affect the degree of epithelial cell damage. In addition, patients $B, C, D$, and $E$ had accepted treatment, while patient $A$ had not been treated. Probably, the treatment reduced the damage of those cells.

Under a microscopic examination, these cytopathic effects cannot be distinguished morphologically whether the effects were due to apoptosis or necrosis. Therefore, it is necessary to perform a further research to prove this issue. Morphological studies of exfoliative cells in saliva associated with damage due to the cytopathic effect of SARS-CoV-2 have never been observed at this time. Since the sensitivity in the detection of SARS-CoV-2 virus is high in saliva [17], further studies with more samples and combined with markers are essential to distinguish cytopathic effects due to apoptosis or necrosis or a combination of both (necroptosis).

The presence of exfoliative cells, including enucleated cells in saliva of clinically healthy mouths people, can be found in small number and these cells appeared as necrotic cells under an electron microscope analysis [13]. We noticed the enucleated cells among exfoliative cells tended to be more common in the saliva of COVID-19 patients in comparison to saliva of control patients. This condition possibly because the process of cell turnover becoming faster, therefore, enucleated cells tend to be accumulated in these people.

Inflammatory reaction is the result of interaction between host and virus and it affects the health status. The presence of inflammatory cells in saliva depends on conditions related to oral cavity [14], [15]. Some conditions that can cause the accumulation of these inflammatory cells in the oral cavity are ulcers, gingivitis, periodontitis, the presence of tumors, dental caries, and even the presence of foreign substances in the oral cavity such as dentures or tooth crowns [11]. Several studies showed that there was a decrease in number of T-lymphocyte cells in the peripheral blood of patients with COVID-19 and in lung tissues of people infected with the SARS-CoV-2 [18] In this study, the density of inflammatory cells was lower in COVID-19 patients as compared to those who were not infected. From these findings, the presence of inflammatory cells in saliva can be used as a parameter to detect the presence of SARSCoV-2 infection among infected people. Therefore, further research is needed along with complete data of the patient's health status to prove this possibility.

\section{Conclusion}

Epithelial cells in saliva of COVID-19 patients showed damage of membranes and organelles. The cytopathological features of exfoliative epithelial cells of saliva can be used as an alternative method for a non-invasive diagnostic test in detecting the presence of the SARS-CoV-2 virus, but more studies are needed. The next phase of the study will include more samples and standardize the samples in terms of the day of the disease, the severity of the initial and current symptoms, as well as the lung involvement condition when the saliva is collected.

\section{Acknowledgment}

This research was supported by a research funding grant of the Hibah Penelitian Inovasi 2020 from Sriwijaya University. The authors gratefully acknowledge those who had contributed their generous support in completing this work.

\section{References}

1. World Health Organization. Naming the Coronavirus Disease (COVID-19) and the Virus that Causes it. Geneva: World 
Health Organization; 2020. Available from: https://www.who. int/emergencies/diseases/novelcoronavirus-2019/technicalguidance/naming-the-coronavirusdisease-(covid-2019)-andthe-virus-that-causes-it. [Last accessed on 2020 Mar 29].

2. World Health Organization. Corona Virus Disease 2019 (COVID-19). Situation Report-127. Geneva: World Health Organization; 2020. Available from: https://www.who.int/docs/ default-source/coronaviruse/situation-reports/20200526COVID-19-sitrep-127.pdf?sfvrsn=7b6655ab_8. [Last accessed on 2020 May 26].https://doi.org/10.26524/ royal.37.10

3. Zhang H, Penninger JM, Li Y, Zhong N, Slutsky AS. Angiotensinconverting enzyme 2 (ACE2) as a SARS-CoV-2 receptor: Molecular mechanisms and potential therapeutic target. Intensive Care Med. 2020;46(4):586-90. https://doi.org/10.1007/ s00134-020-05985-9

PMid:32125455

4. Roossinck MJ. Virus: An Illustrated Guide to 101 Incredible Microbes. Princeton and Oxford: Princeton University Press; 2016. https://doi.org/10.2307/j.ctvc77dwh

5. Liu Y, Gayle AA, Wilder-Smith A, Rocklöv J. The reproductive number of COVID-19 is higher compared to SARS coronavirus. J Travel Med. 2020;27(2):taaa021. https://doi.org/10.1093/jtm/ taaa021

PMid:32052846

6. World Health Organization. Laboratory Testing for Coronavirus Disease 2019 (COVID-19) in Suspected Human Cases. Geneva: World Health Organization; 2020.

7. To KK, Tsang OT, Yip CC, Chan KH, Wu TC, Chan JM, et al. Consistent detection of 2019 novel coronavirus in saliva. Clin Infect Dis. 2020;71(15):841-3.

8. Navazesh M, Kumar SK. Measuring salivary flow: Challenges and opportunities. J Am Dent Assoc. 2008;139 Suppl:35S-40. PMid:18460678

9. Marcantoni M. Ecology of the oral cavity. In: Gastroenterology Microbiology. Fundamentals and practical guide. Negroni M Ed., Medica Panamericana. 2a ed. Buenos Aires. 2009; pp.225-231.

10. Kaufman E, Lamster IB. The diagnostic applications of saliva--a review. Crit Rev Oral Biol Med. 2002;13(2):197-212.

\section{PMid:12097361}

11. Theda C, Hwang SH, Czajko A, Loke YJ, Leong P, Craig JM. Quantitation of the cellular content of saliva and buccal swab samples. Sci Rep 2018;8:6944. https://doi.org/10.1038/ s41598-018-25311-0

12. Agol V. Cytopathic effects: Virus-modulated manifestations of innate immunity? Trends Microbiol. 2012;20(12):570-6. https:// doi.org/10.1016/j.tim.2012.09.003

PMid:23072900

13. Collan $\mathrm{Y}$, Raeste AM. Electron microscopy of exfoliated cells of human oral mucosa. Scand J Dent Res. 1978;86(5):374-85. https://doi.org/10.1111/j.1600-0722.1978.tb00640.x PMid:281758

14. Cuevas-Córdoba B, Santiago-García J. Saliva: A fluid of study for OMICS. OMICS. 2014;18(2):87-97. https://doi.org/10.1089/ omi.2013.0064

PMid:24404837

15. Schafer CA, Schafer JJ, Yakob M, Lima P, Camargo P, Won DT. Saliva diagnostics: Utilizing oral fluids to determine health status. In: Ligtenberg AJ, Veerman EC, editors. Saliva: Secretion and Functions. Vol. 24. Basel: Karger Publishers; 2014. p. 88-98. https://doi.org/10.1159/000358791

16. Asai $D$, Nakashima H. Pathogenic viruses commonly present in the oral cavity and relevant antiviral compounds derived from natural products. Medicines (Basel). 2018;5(4):120. https://doi. org/10.3390/medicines 5040120

PMid:30424484

17. Wyllie AL, Fournier J, Casanovas-Massana A, Campbell M, Tokuyama M, Vijayakumar P. Saliva is More Sensitive for SARSCoV-2 Detection in COVID-19 Patients than Nasopharyngeal Swabs. New York: medRxiv; 2020. Available from: https:// www.medrxiv.org/content/10.1101/2020.04.16.20067835v1.full. pdf. [Last accessed on 2020 May 30]. https://doi.org/10.341 0/f.737795545.793573919

18. Wang C, Xie J, Fei X, Zhang H, Tan Y, Zhou L. Alveolar macrophage dysfunction and cytokine storm in the pathogenesis of two severe COVID-19 patients. Lancet. 2020;57:102833. Available from: https://www.researchsquare.com/article/ rs-19346/v1. [Last accessed on 2020 May 30]. https://doi. org/10.1016/j.ebiom.2020.102833 